\title{
LAND SUBSIDENCE CAUSED \\ BY DISSOLUTION OF SALT NEAR \\ FOUR OIL AND GAS WELLS \\ IN CENTRAL KANSAS
}

U.S. GEOLOGICAL SURVEY

Water-Resources Investigations 27-75

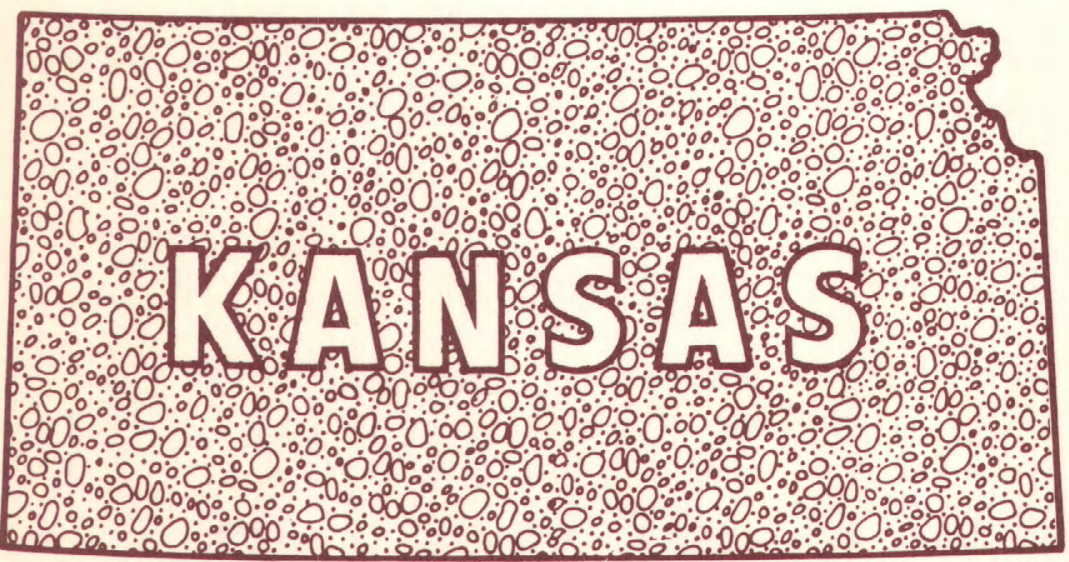

Prepared for the Energy Research and Development Administration

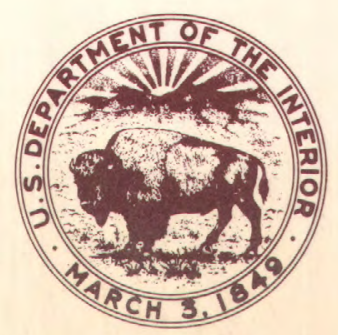




\begin{tabular}{|c|c|c|}
\hline $\begin{array}{l}\text { BIBLIOGRAPHIC DATA } \\
\text { SHEET }\end{array}$ & 1. Report No. & 3. Recipient's Accession No. \\
\hline \multirow{2}{*}{\multicolumn{2}{|c|}{$\begin{array}{l}\text { 4. Title and Subtitle } \\
\text { LAND SUBSIDENCE CAUSED BY DISSOLUTION OF SALT } \\
\text { NEAR FOUR OIL AND GAS WELLS IN CENTRAL KANSAS }\end{array}$}} & $\begin{array}{l}\text { 5. Report Date } \\
\text { September } 1975\end{array}$ \\
\hline & & 6. \\
\hline \multicolumn{2}{|c|}{$\begin{array}{l}\text { 7. Author(s) } \\
\text { Stuart W. Fader }\end{array}$} & $\begin{array}{l}\text { 8. Performing Organization Rept. } \\
\text { No. WRI } 27-75\end{array}$ \\
\hline \multirow{2}{*}{\multicolumn{2}{|c|}{$\begin{array}{l}\text { 9. Performing Organization Name and Address } \\
\text { U.S. Geological Survey } \\
1950 \text { Avenue A--Campus West } \\
\text { Kansas University } \\
\text { Lawrence, Kansas } 66045\end{array}$}} & 10. Project/Task/Work Unit No. \\
\hline & & 11. Contract/Grant No. \\
\hline \multirow{2}{*}{\multicolumn{2}{|c|}{$\begin{array}{l}\text { 12. Sponsoring Organization Name and Address } \\
\text { U.S. Geological Survey } \\
1950 \text { Avenue A--Campus West } \\
\text { Kansas University } \\
\text { Lawrence, Kansas } 66045\end{array}$}} & $\begin{array}{l}\text { 13. Type of Report \& Period } \\
\text { Covered } \\
\text { Final }\end{array}$ \\
\hline & & 14. \\
\hline
\end{tabular}

15. Supplementary Notes

Report prepared for Energy Research and Development Administration

16. Abstracts Land subsidence near abandoned oil and gas wells in central Kansas has resulted from the dissolution and removal of salt by downward-moving ground water. At four sites investigated for this report, the failure of well casings or plugs has allowed water from near-surface formations to come in contact with and dissolve salt in the Wellington Formation. The resulting brine is discharged to older formations beneath the salt. More than 4 million cubic feet $(113,000$ cubic metres) of salt is estimated to have been removed by dissolution at a site in Russell County. Land subsidence at that site averages about 1 foot ( 0.3 metre) per year and an area about 1,000 feet ( 300 metres) in diameter has been affected in a period of 30 years. The lateral extent of subsidence in the salt zone is believed to be less than 660 feet (200 metres) from the abandoned wells.

17. Key Words and Document Analysis. 17a. Descriptors

*Land subsidence, *Dissolution of salt, Ground-water movement

17b. Identifiers/Open-Ended Terms

Central Kansas

17c. COSATI Field/Group

\begin{tabular}{|c|c|c|}
\hline $\begin{array}{c}\text { 18. Availability Statement } \\
\text { No restriction on distribution }\end{array}$ & $\begin{array}{l}\text { 19. Security Class (This } \\
\text { Report) } \\
\text { UNCLASSIFIED }\end{array}$ & $\begin{array}{l}21 . \text { No. of Pages } \\
28\end{array}$ \\
\cline { 2 - 4 } & $\begin{array}{l}\text { 20. Security Class (This } \\
\text { Page } \\
\text { UNCLASSIFIED }\end{array}$ & $\begin{array}{l}\text { 22. Price } \\
\text { FORM NTIS-35 (REV.10-73) ENDORSED BY ANSI AND UNESCO. }\end{array}$ \\
\hline
\end{tabular}




\section{LAND SUBSIDENCE CAUSED BY}

\section{DISSOLUTION OF SALT NEAR FOUR}

OIL AND GAS WELLS IN CENTRAL KANSAS

By Stuart W. Fader

U. S. GEOLOGICAL SURVEY

Water-Resources Investigations 27-75

Prepared for the

Energy Research and

Development Administration

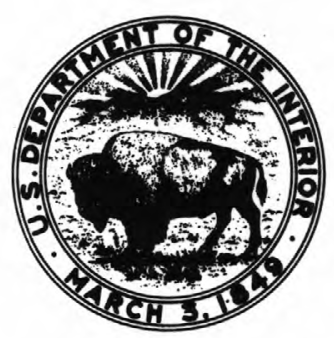




\section{UNITED STATES DEPARTMENT OF THE INTERIOR GEOLOGICAL SURVEY \\ V. E. McKelvey, Director}

For additional information write to:

U. S. Geological Survey

1950 Avenue "A" - Campus West

Kansas University Lawrence, Kansas 66045 
Abstract - . - . - _ . . - - . . . - - 1

Conversion factors from English to metric units - . - - - 2

Introduction - . - . - . . . . . . . . - 3

Site $1 \ldots \ldots$

Location - . . . . . . . . . . - 5

Historical information _ - . - . - . - . - 5

Geologic and hydrologic characteristics - - - - - - 10

Subsidence _. - . . . . . . . . . . 10

Concentration of chloride ion - - - - - - - - 12

Fluid levels - . . . . . . . . . . . . 14

Direction and rate of movement of fluid - . - - - - 17

Site 2 - . . . . . . . . . . . 18

Location - . . . . . . . . . . . . 18

Historical information - - . - . - . - . - - 18

Geologic and hydrologic characteristics - . - . - - 18

Subsidence - . . - . . . . . . . . - 18

Concentration of chloride ion - . . . . . . - 20

Fluid levels _. . . . . . . . . . . . - 20

Direction and rate of movement of fluid _. . . . - 20

Site 3 - . . . - . . . . . . . - - 22

Location - - - . - - - . - . - . - 22

Historical information - . - . - . . . . 23

Geologic and hydrologic characteristics - - - - - - 23

Subsidence _. . . . . . . . . . . . 23

Concentration of chloride ion - - - - - - - . - 24

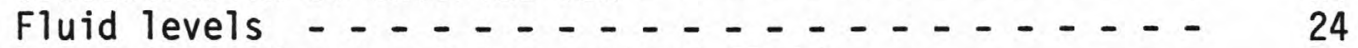

Site 4 irection and rate of movement of fluid $\ldots$

Location - . - - - - - - . - - . 26

Historical information _. . . . . . . . . 26

Geologic and hydrologic characteristics - - - - - - - 26

Subsidence - . . - . . . . . . - . - 27

Concentration of chloride ion - . - . - . - . - 27

Fluid levels _. - . . . . . . . . . . - 27

Direction and rate of movement of fluid - . - . . - 27

Conclusions _. . . . . . . . . . . . - 28

Selected References _ - . . . . . . . - . . 28 
Figure

1. Map of Kansas showing location of study sites - - - - 4

2. Photograph of deteriorated casing from an abandoned oil well and related water-filled sink in Rice County - . . . . . - . - . - -

3. Photographs of subsidence pond at Site 1 (1972):
A, looking northeast; B, looking south - - - - - 6

4. Sketch of Site 1, showing locations of wells

in relation to the highway - - . - . - . - . - 7

5. Profiles of center line of east-bound lane of Interstate Highway 70 at Site 1 - - - - - - 11

6. Logs of wells at Site 1 showing altitudes of formational contacts at selected times - - - . - -

7. Hydrographs showing fluid levels in Kansas Highway Commission test wells at Site 1 _. - . - 16

8. Sketch of Site 2, showing location of well in relation to the highway _... . . . . . . 19

9. Profiles of center line of east-bound lane of Interstate Highway 70 at Site 2 - - - . - - -

10. Photographs of Site 3: $\underline{A}$, looking north at eroded pond; $B$, looking east at surface depression at fence along south side of site - . - - 22

11. Photographs of Site 4 , looking northeast at subsidence pond _... . . . . . . . . -

Table

TABLES

1. Generalized geologic section for four selected sites, central Kansas _. . . . . . . . . . Page Historical records and construction details for wells at four selected sites, central Kansas - - - - - 


\title{
LAND SUBSIDENCE CAUSED BY DISSOLUTION OF SALT \\ NEAR FOUR OIL AND GAS WELLS IN CENTRAL KANSAS
}

S. W. Fader

\begin{abstract}
Land subsidence near abandoned oil and gas wells in central Kansas has resulted from the dissolution and removal of salt by downward-moving ground water. At four sites investigated for this report, the failure of well casings or plugs has allowed water from near-surface formations to come in contact with and dissolve salt in the Wellington Formation. The resulting brine is discharged to older formations beneath the salt. More than 4 million cubic feet $(113,000$ cubic metres) of salt is estimated to have been removed by dissolution at a site in Russell County. Land subsidence at that site averages about 1 foot ( 0.3 metre) per year and an area about 1,000 feet (300 metres) in diameter has been affected in a period of 30 years. The lateral extent of subsidence in the salt zone is believed to be less than 660 feet ( 200 metres) from the abandoned wells.
\end{abstract}


For those readers interested in or accustomed to using the metric system of measurement, English units of measurement given in this report are followed by equivalent metric units (in parentheses) using the following abbreviations and conversion factors:

\section{English units}

Length

inches (in)

feet $(\mathrm{ft})$

miles (mi)

Volume

$\begin{array}{lcl}\text { gallons }(\mathrm{gal}) & 3.785 \times 10^{-3} & \text { cubic metres }\left(\mathrm{m}^{3}\right) \\ \text { barrels }(\mathrm{bbl}) & .1590 & \text { cubic metres }\left(\mathrm{m}^{3}\right) \\ \text { cubic feet }\left(\mathrm{ft}^{3}\right) & .02832 & \text { cubic metres }\left(\mathrm{m}^{3}\right)\end{array}$

Pressure

pounds per square
inch $\left(1 \mathrm{bs} / \mathrm{in}^{2}\right)$

7.1

Flow

gallons per minute (gal/min)
Multiply by

Metric units
25.4

.3048

1.609 millimetres ( $\mathrm{mm}$ )

metres (m)

kilometres $(\mathrm{km})$ kilopascals ( $\mathrm{kPa})$

.06309 litres per second $(1 / 5)$ 
Collapse of the overlying strata into voids caused by dissolution of salt is the apparent cause of progressive land subsidence at the sites of several oil wells that were drilled through the salt beds of the Wellington Formation in Kansas. The purpose of this investigation was to determine if data from four sites, shown in figure 1, substantiate the hypothes is that corroded, broken, or improperly sealed casing permitted relatively fresh water from the shallow aquifers to circulate within the salt zone and that the resulting brine solution leaked downward into permeable zones that would accept the fluid under hydrostatic pressure.

Strata similar to those penetrated by wells at the four sites (shown in tables 1 and 2) underlie much of central Kansas. Many thousands of $0 i 1$ and gas wells have been drilled through the salt beds, but land subsidence has been reported at few of the sites. Reported sites are near highways, and two well-documented instances of subsidence involve the stability of highway right-of-way. Because many wells have been drilled in remote areas, similar occurrences may remain unreported. The scope of this investigation is limited to the compilation, analysis and interpretation of the available data from four sites shown in figure 1 , and the mention of a fifth site.

The photograph (fig. 2) shows a deteriorated casing pulled from a well located between Sites 3 and 4 in western Rice County. The casing consists of inner and outer pipes with the annular space between filled with cement. The almost complete failure of the outer pipe is evident. The casing is believed to be from the well in the concrete pit that is in the lower right of the photograph. The pond in the background is a sink that has developed near the well; detailed historical data, however, were unavailable for further study of this site.

The investigation was requested by the Energy Research and Development Administration (formerly U.S. Atomic Energy Commission) as part of a study of bedded salt in Kansas as a repository for radioactive wastes. Data for the report were collected from the files of several Kansas State agencies; the Highway Commission, Department of Health and Environment, Geological Survey, and the Corporation Commission. The author particularly wishes to thank V. A. Burgat and W. K. Taylor of the Highway Commission; B. F. Latta, D. L. Butcher, and M. W. Glotzback of the Department of Health and Environment; and F. W. Wilson of the Geological Survey for information based on personal observations and for resolving apparent contradictions in the available data.

The geologic formations that underlie the four sites selected for this study are described in table 1 and information about the oil and gas wells at the sites is given in table 2. 


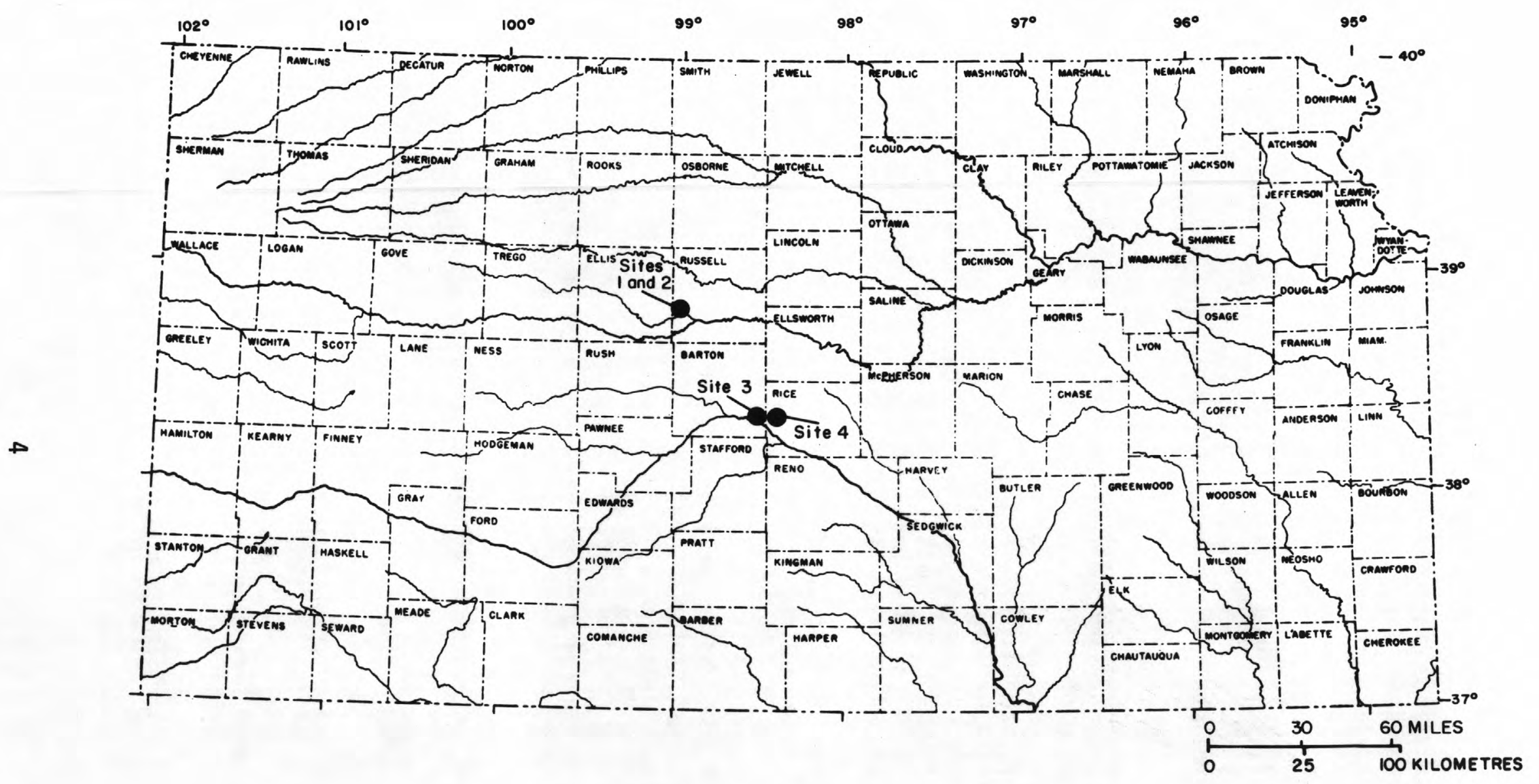

Figure 1.--Map of Kansas showing location of study sites. 


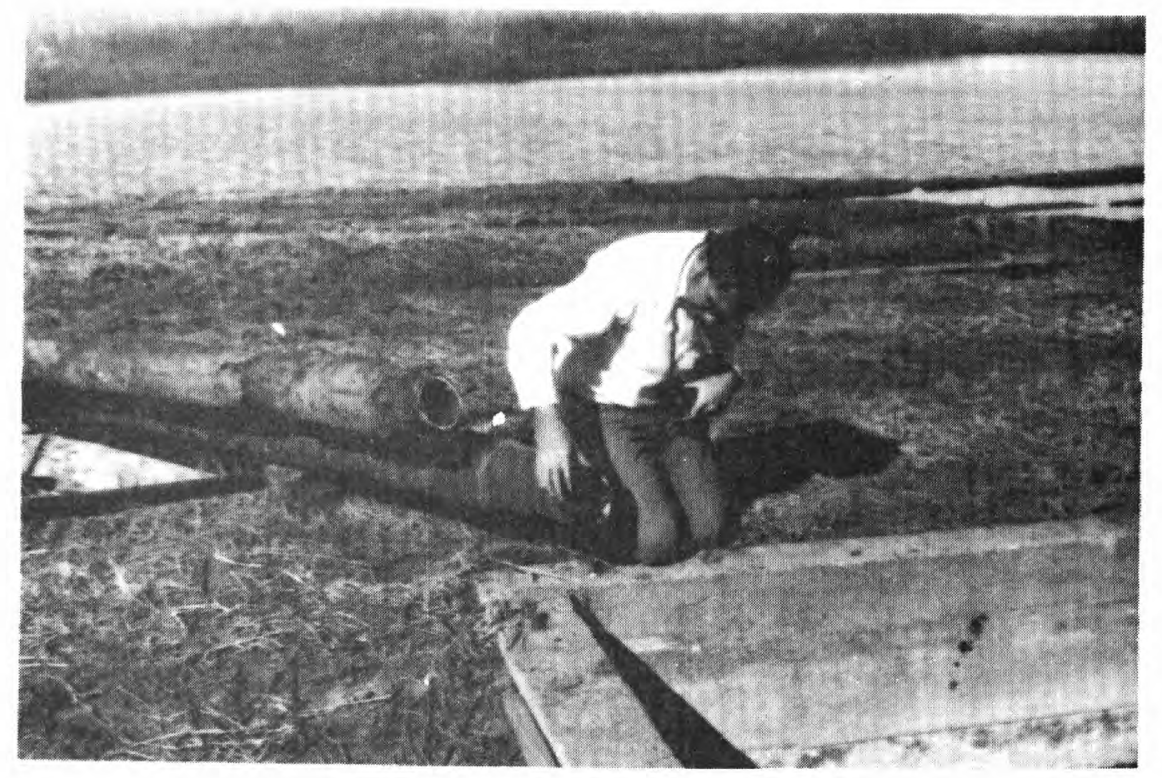

Figure 2.--Deteriorated casing from an abandoned oil well and related water-filled sink in Rice County.

\section{SITE 1}

\section{Location}

The sink at Site 1 is centered around two abandoned oil wells in the NW $\frac{1}{4} N W_{1}^{\frac{1}{4}} \mathrm{SW}^{\frac{1}{4}}$ sec.2, T.14 S., R.15 W., in western Russel1 County. Photographs of the site are shown in figure 3 and the locations of wells drilled at the site in relation to Interstate Highway 70 are shown in figure 4.

\section{Historical Information}

$0 i 1$ production in the area began in 1935 and more than 50 wells have been drilled within $0.5 \mathrm{mi}(0.8 \mathrm{~km})$ of Site 1 . Two well s, designated Crawford 12 and Crawford 16, were drilled in 1937. Two wells, designated KHC (Kansas Highway Commission) water-supply well and KHC exploratory wel1, were drilled in 1966 and 1967 respectively at the Site.

Wells were drilled in the area for disposal of oil-field brine as early as 1936. Several of the wells were drilled within $0.5 \mathrm{mi}(0.8 \mathrm{~km})$ of Site 1. Most of the disposal wells were abandoned and plugged prior to February 1972. There are no records of disposal wells within the area of subsidence; the nearest disposal wel1 was about 1,450 ft (440 m) southeast of Crawford 16. Salt water produced with oil from the rocks in the Lansing and Kansas City Groups was disposed through wells in the Dakota Formation, Cheyenne Sandstone, and Cedar Hills Sandstone. The rate of disposal into these formations apparently was inadequate because most of the salt water has been transported by pipeline to a more favorable area 4 or $5 \mathrm{mi}(6$ or $8 \mathrm{~km})$ to the southwest. 

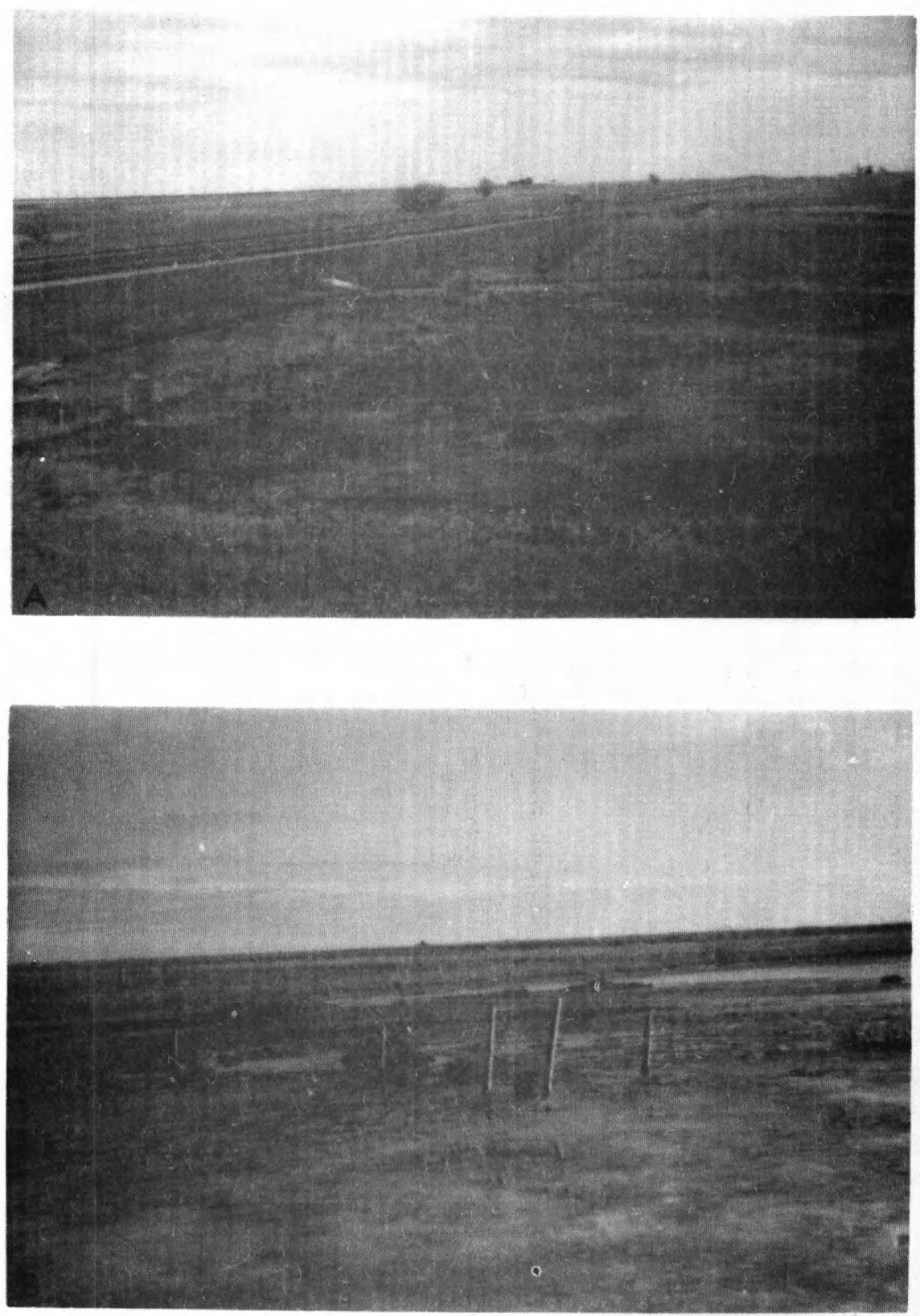

Figure 3.--Subsidence pond at Site 1 (1972);

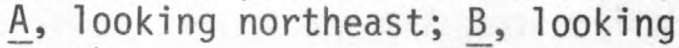
south. 


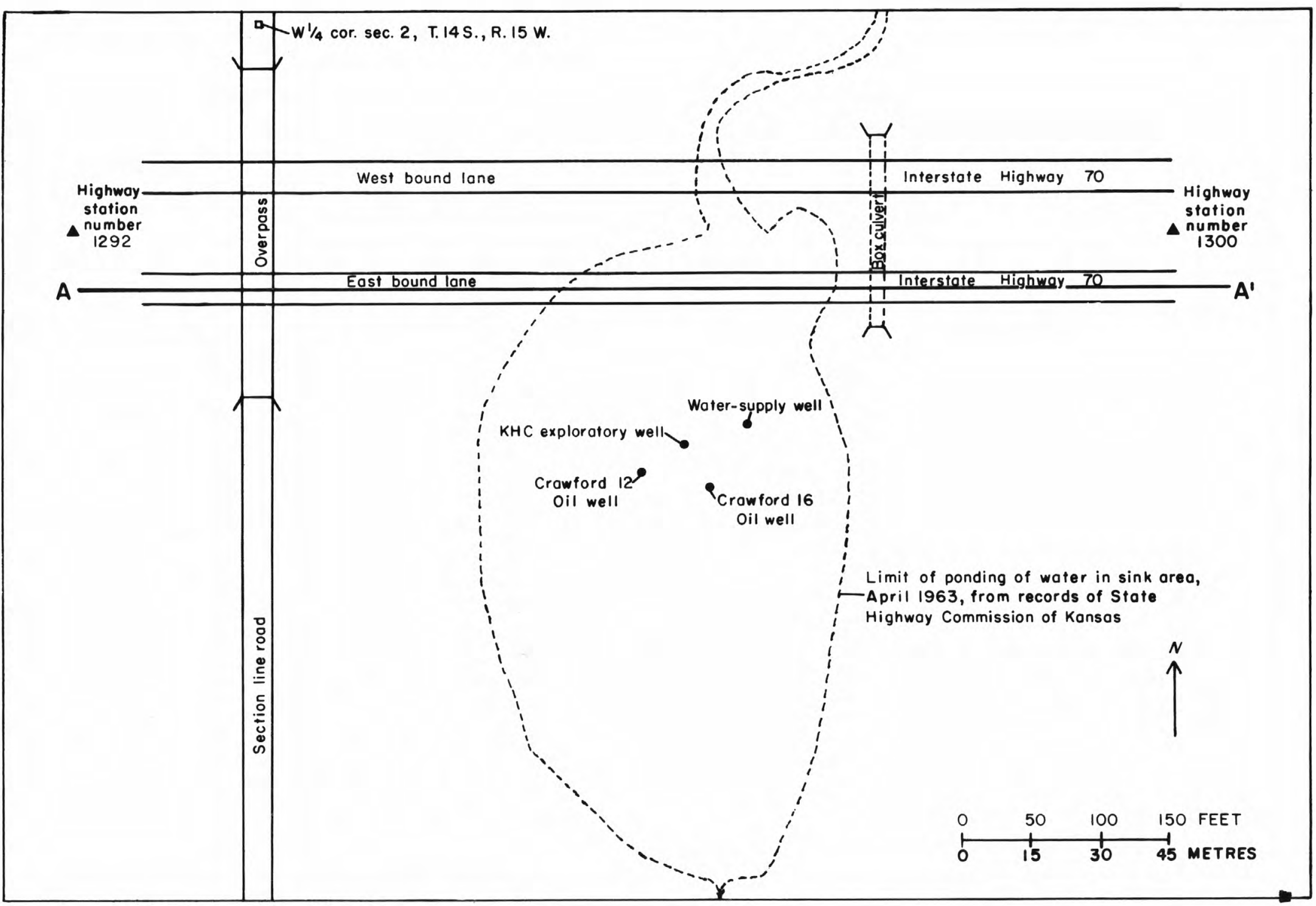

Figure 4.--Sketch of Site 1, showing location of wells in relation to the highway. 
Table 1.--Generalized stratigraphic section for four selected sites, central Kansas. ${ }^{1}$

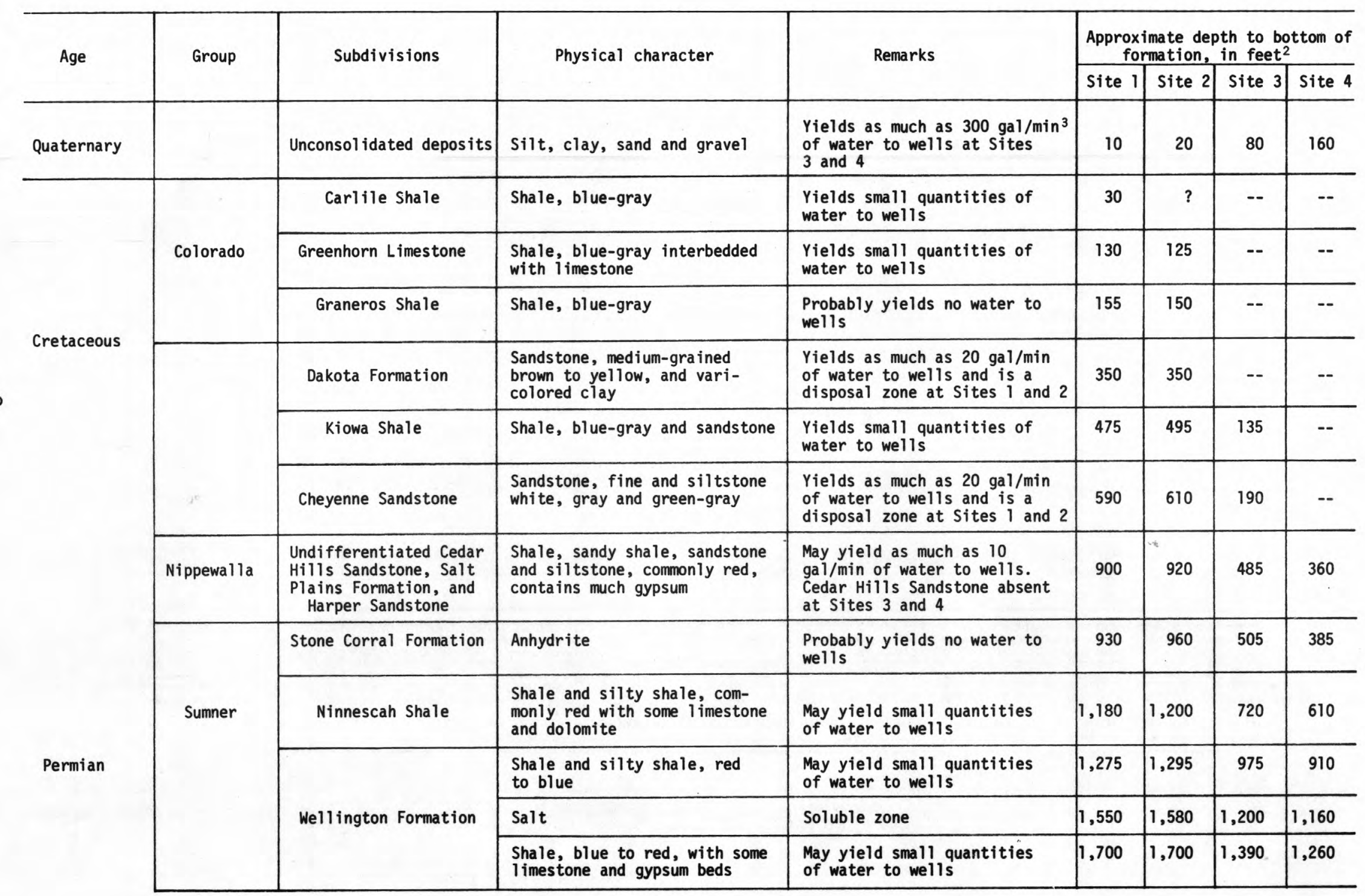




\begin{tabular}{|c|c|c|c|c|c|c|c|c|}
\hline & Chase & \multirow{8}{*}{$\begin{array}{l}\text { Individual formations } \\
\text { in Chase through } \\
\text { Arbuckle Groups listed } \\
\text { separately }\end{array}$} & $\begin{array}{l}\text { Limestone interbedded with } \\
\text { shale }\end{array}$ & \multirow{6}{*}{$\begin{array}{l}\text { Probably would accept small } \\
\text { quantities of water under } \\
\text { pressure }\end{array}$} & 2,020 & 2,040 & 1,750 & 1,650 \\
\hline & Council Grove & & $\begin{array}{l}\text { Limestone interbedded with } \\
\text { shale }\end{array}$ & & 2,320 & 2,335 & 2,060 & 1,990 \\
\hline & Admire & & $\begin{array}{l}\text { Shale with few thin limestone } \\
\text { and coal beds }\end{array}$ & & 2,400 & 2,395 & 2,140 & 2,070 \\
\hline \multirow{4}{*}{ Pennsylvanian } & Wabaunsee & & $\begin{array}{l}\text { Shale with thin limestone } \\
\text { beds, and some sandstone }\end{array}$ & & 2,740 & 2,760 & 2,600 & 2,520 \\
\hline & Shawnee & & $\begin{array}{l}\text { Limestone, massive inter- } \\
\text { bedded with shale }\end{array}$ & & 3,000 & 3,010 & 2,900 & 2,840 \\
\hline & Douglas & & $\begin{array}{l}\text { Shale, with few thin lime- } \\
\text { stone and coal beds }\end{array}$ & & 3,010 & 3,020 & 2,990 & 2,900 \\
\hline & $\begin{array}{l}\text { Undifferen- } \\
\text { tiated } \\
\text { Lansing and } \\
\text { Kansas City }\end{array}$ & & $\begin{array}{l}\text { Limestone, with few shale beds } \\
\text { At Sites } 1 \text { and } 2 \text {, contains } \\
\text { sandstone and conglomerate } \\
\text { locally termed "Gorham sand" }\end{array}$ & $\begin{array}{l}\text { 0il-producing zone; probably } \\
\text { would accept small quantities } \\
\text { of water under pressure in } \\
\text { upper part }\end{array}$ & 3,308 & 3,305 & 3,300 & 3,275 \\
\hline $\begin{array}{l}\text { Ordovician } \\
\text { and Cambrian } \\
\text { undifferen- } \\
\quad \text { tiated }\end{array}$ & Arbuckle & & $\begin{array}{l}\text { Dolomite, cherty, dolomite } \\
\text { and sandstone beds, locally } \\
\text { cavernous }\end{array}$ & $\begin{array}{l}\text { Oil-producing. Commonly used } \\
\text { for disposal of salt water }\end{array}$ & -- & -- & 3,850 & 3,540 \\
\hline Precambrian & & & $\begin{array}{l}\text { Conglomerate containing sand, } \\
\text { shale, and chert gravel. } \\
\text { Localiy termed "granite wash" }\end{array}$ & $\begin{array}{l}\text { 0il-producing zone; probably } \\
\text { would accept small quantities } \\
\text { of water under pressure }\end{array}$ & & & -- & -- \\
\hline
\end{tabular}

1 The classification and nomenclature of rock units used in this report are those of the U.S. Geological Survey and differ somewhat from those of the Kansas Geological Survey.

2 Feet multiplied by 0.3048 equivalent to metres.

3 Gallons per minute multiplied by 0.06309 equivalent to litres per second. 
Secondary recovery of oil by water flooding began in 1963. Salt water produced with the oil was injected back into the oil-producing formations through nine wells located in the north half of section 3 . The nearest injection well used for secondary recovery was located about $360 \mathrm{ft}(110 \mathrm{~m})$ north and $450 \mathrm{ft}(140 \mathrm{~m})$ west of Crawford 12 . This well was abandoned in 1966. A water-flooding operation in February 1972 injected about 7,800 bbl $\left(1,200 \mathrm{~m}^{3}\right)$ of water per day under a surface pressure of about 500 1bs/in ${ }^{2}(3,500 \mathrm{kPa})$. Geologists of the Kansas Department of Health and Environment report that this rate and pressure are sufficient to drive oil and water to the pumps for the production zone, but are not sufficient to force fluid up into the salt zones at the producing wells.

\section{Geologic and Hydrologic Characteristics}

Lithologic characteristics of the stratigraphic units at Site 1 are described in the generalized geologic section shown in table 1 . The sandstones above the salt beds in the Wellington and the unconsolidated deposits near the land surface are potential sources of water for dissolution of the salt. The limestones, dolomite, and conglomerate below the salt generally will accept water under hydrostatic head.

\section{Subsidence}

Land subsidence at Site 1 was reported by oil-field workers in the early 1950's. A pond with surface dimensions of about 250 by $450 \mathrm{ft}$ ( 76 by $140 \mathrm{~m}$ ) in 1959 had increased in size to about 270 by $470 \mathrm{ft}$ ( 80 by $145 \mathrm{~m}$ ) by 1963. Construction of Interstate Highway 70 through the northern part of the pond in 1963 precludes further estimates of the pond size. Continued subsidence has adversely affected Interstate Highway 70. The profiles shown in figure 5 indicate that the highway at station 1296 has subsided nearly $3 \mathrm{ft}(1 \mathrm{~m})$ during 1964-70. A reference point near Crawford 16 subsided about $4 \mathrm{ft}(1.2 \mathrm{~m})$ from March 1966 to July 1970.

In 1937 the altitude of the land surface above mean sea level was $1,867 \mathrm{ft}(569.1 \mathrm{~m})$ at Crawford 12 and $1,869 \mathrm{ft}(569.7 \mathrm{~m})$ at Crawford 16 . At the location of the KHC exploratory hole (fig. 4) the altitude of the 1 and surface was estimated to be $1,868 \mathrm{ft}(569.4 \mathrm{~m})$ in 1937 and was measured as 1,861.5 ft $(567.4 \mathrm{~m})$ on September 8, 1967 and 1,858.0 ft (566.3 m) on July 22, 1970.

Based on these altitudes, the subsidence near the wells was approximately $6.5 \mathrm{ft}(2 \mathrm{~m})$ during $1937-67$ and approximately $3.5 \mathrm{ft}(1 \mathrm{~m})$ during 1967-70. The diameter of the area of surface subsidence was estimated to be about $1,000 \mathrm{ft}(300 \mathrm{~m})$ from the projections of the profiles (fig. 5) to the points of intersection. The effects on subsidence in the pond area of siltation from wind and rainfall runoff and the addition of roadfill during highway construction could not be determined. The rate of subsidence is larger for the later periods of time, but the significance of the change in rate is unknown. 


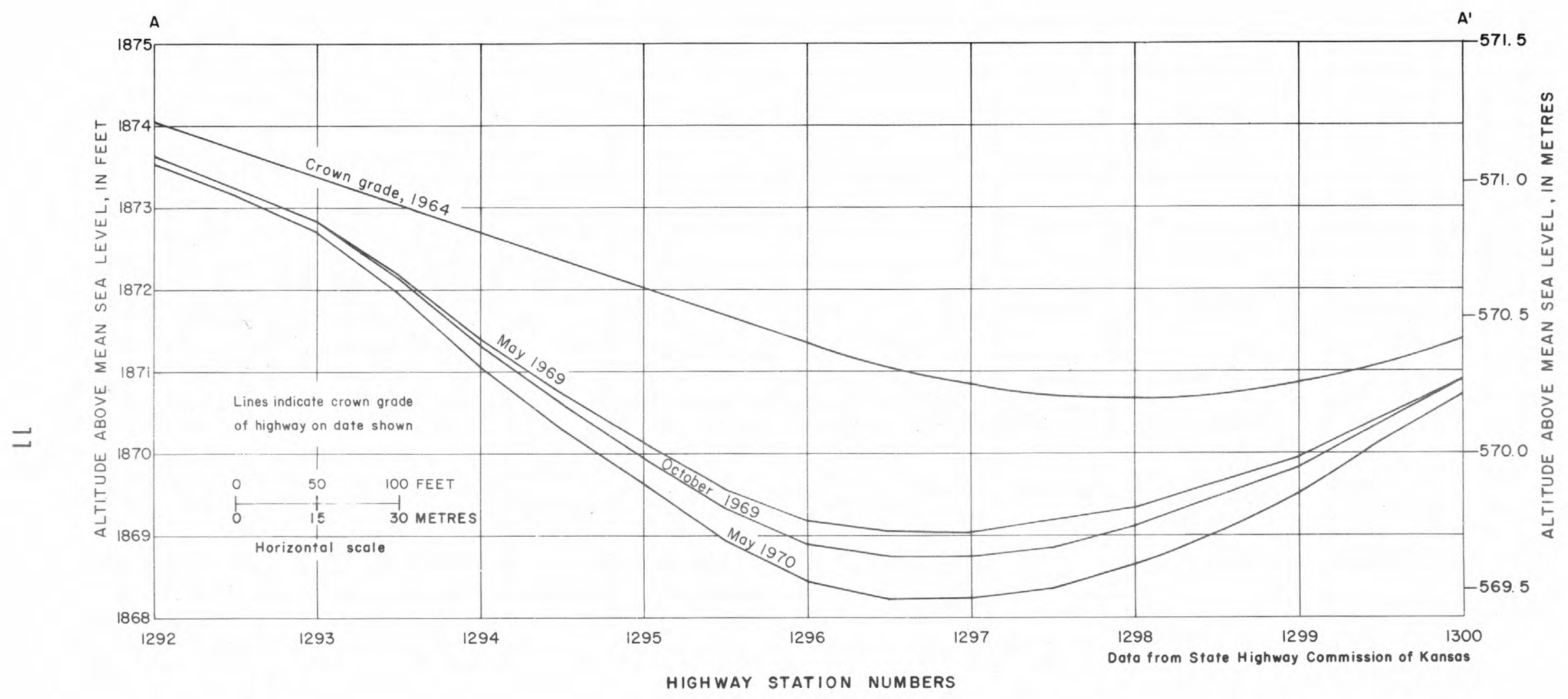

Figure 5.--Profiles of center line of east-bound lane of Interstate Highway 70 at Site 1. 
The configuration of a shallow 1 imestone marker bed $26 \mathrm{ft}(8 \mathrm{~m})$ below the land surface in Crawford 16 and in test holes drilled by the Kansas Highway Commission indicates that the sink is a roughly circular cone about 1,000 ft $(300 \mathrm{~m})$ in diameter in 1966. The subsidence of the marker bed during 1937-66 was about $14 \mathrm{ft}(4 \mathrm{~m})$. If this subsidence continued at about the same rate as that of the surface subsidence during 1967-70 (3.5 ft or $1 \mathrm{~m})$, the total subsidence of the marker bed during 1967-70 would be about $18 \mathrm{ft}(5 \mathrm{~m})$.

The altitudes of the formational contacts from drillers logs of wells Crawford 12 and 16, a geologists $10 \mathrm{~g}$ of a well $660 \mathrm{ft}(200 \mathrm{~m})$ north of Crawford 12 and from the drillers and gamma ray-neutron logs of the KHC well are illustrated in figure 6. The top of the Dakota Formation subsided about $15 \mathrm{ft}(5 \mathrm{~m})$, the top of the Nippewalla Group and the Stone Corral Formation subsided about $40 \mathrm{ft}(12 \mathrm{~m})$ and the salt unit of the Wellington Formation was reduced in thickness by about $50 \mathrm{ft}(15 \mathrm{~m})$ at Site 1 during 1937-67. Drilling records of the KHC well show that the drill bit dropped $10 \mathrm{ft}(3 \mathrm{~m})$ into a void at the top of the Stone Corral Formation indicating probable differential subsidence or separation of strata above the salt. There is no evidence of subsidence at the well drilled $660 \mathrm{ft}(200 \mathrm{~m})$ north of Crawford 12 in 1966. Because of bridging of the strata overlying the partly dissolved salt beds and because of the bulking of the slumped rock, the volume of salt removed probably exceeds the apparent volume of subsidence at the land surface.

By assuming that the shape of the surface subsidence is roughly a right circular cone about $1,000 \mathrm{ft}(300 \mathrm{~m})$ in diameter and with a height of $10 \mathrm{ft}(3 \mathrm{~m})$, the volume of salt removed would be at least $2,600,000 \mathrm{ft}^{3}\left(74,000 \mathrm{~m}^{3}\right)$. If the subsidence of $18 \mathrm{ft}(5 \mathrm{~m})$ for the shallow limestone marker bed is used, the volume of salt removed during 1937-70 would be at least $4,700,000 \mathrm{ft}^{3}\left(133,000 \mathrm{~m}^{3}\right)$. If the salt removed is assumed to be in the shape of a right circular cone with a volume of $4,700,000 \mathrm{ft}^{3}\left(133,000 \mathrm{~m}^{3}\right)$ and a height of $50 \mathrm{ft}(15 \mathrm{~m})$, the reduced thickness of the salt zone at the $\mathrm{KHC}$ well, the diameter of subsidence at the top of the salt in the Wellington Formation would be about $600 \mathrm{ft}(180 \mathrm{~m})$.

\section{Concentration of Chloride Ion}

The concentrations of chloride in water from wells at Site 1 ranged as follows: Greenhorn Limestone, 1,200 to 8,300 ppm (parts per million); Dakota Formation and Kiowa Shale, 1,000 to 3,500 ppm; Cheyenne

${ }^{1}$ Chloride concentrations given in this report were obtained from chemical analyses by the Kansas Department of Health and Environment and the U.S. Bureau of Mines. Because fluid densities were not recorded in the analyses, concentrations determined in parts per million were not converted to metric equivalent milligrams per litre. 


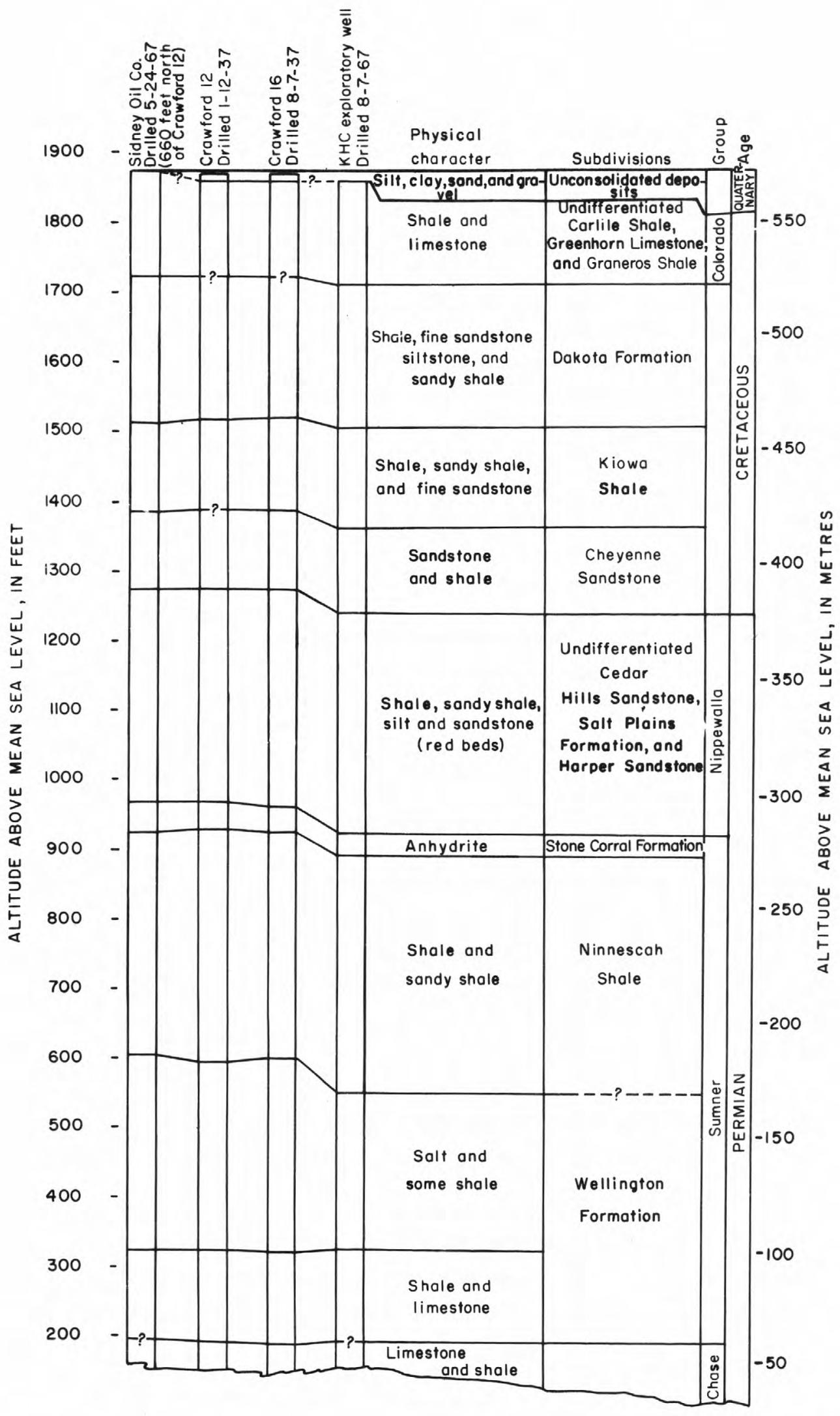

Figure 6.--Logs of wells at Site 1 showing altitudes of formational contacts at selected times. 
and Cedar Hills Sandstones, 2,100 to 3,200 ppm; and the Kansas City and Lansing Groups 13,000 to $150,000 \mathrm{ppm}$. However, the maximum chloride concentration in water from the Lansing and Kansas City Groups was probably about 87,000 ppm before water-flooding began. The water containing 150,000 ppm chloride was pumped from an 0 il well about 1,320 ft $(400 \mathrm{~m})$ west of Crawford 12 during the water-flooding. The anomalously high concentration of chloride suggests circulation through the salt of at least part of the produced water, a factor which may have contributed to the excessive water-oil ratio that caused abandonment of the well.

\section{Fluid Levels}

The fluid level in Crawford 12 at the completion of drilling in January 1937 was reported to be about 1,400 ft $(430 \mathrm{~m})$ above the bottom of the well. The fluid level in Crawford 16 in August 1937 was reported to be about $1,840 \mathrm{ft}(560 \mathrm{~m})$ above the bottom of the well. Thus, it appears that the fluid level for wells producing from the Lansing and Kansas City Groups ranged from about 1,450 to 1,660 ft (440 to $510 \mathrm{~m}$ ) below the land surface (table 2).

When the KHC exploratory well was drilled in 1967, a 8 5/8-in $(219-\mathrm{mm})$ casing was set to a depth of $450 \mathrm{ft}(137 \mathrm{~m})$ and the annular space from 225 to $450 \mathrm{ft}(69$ to $137 \mathrm{~m})$ was cemented. Then the well was drilled to $1,638 \mathrm{ft}(499 \mathrm{~m})$ and a $41 / 2$-in $(114-\mathrm{mm})$ casing was set with cement in the annular space from 1,370 to $1,638 \mathrm{ft}(418$ to $499 \mathrm{~m})$. At that time, there was no fluid inside the $41 / 2-$ in $(114-\mathrm{mm})$ casing and the fluid level between the $41 / 2-$ and 8 5/8-in (114- and 219-mm) casings was about $230 \mathrm{ft}(70 \mathrm{~m})$ below the surface. The casing collapsed or broke at a depth of $947 \mathrm{ft}(289 \mathrm{~m})$ permitting the fluid level inside the $41 / 2$-in (114-mm) casing to stabilize at about $300 \mathrm{ft}(90 \mathrm{~m})$ below the surface by March 1969 (fig. 7). This fluid level probably represents the potentiometric surface of water in the Permian rocks above the salt, primarily the Cedar Hills Sandstone. Sometime after June 1970 the casing collapsed or broke again at about $470 \mathrm{ft}(145 \mathrm{~m})$ below the land surface. Fluid levels inside the $41 / 2-$ in $(114-\mathrm{mm})$ casing and in the space between the $41 / 2-$ and 8 5/8-in (114- and 219-mm) casings equalized by July 1971. The fluid level of $231 \mathrm{ft}(70 \mathrm{~m})$ below the land surface is believed to represent the potentiometric surface for water in the lower part of the Dakota Formation. The potentiometric surface for water in the upper part of the Dakota Formation is believed to be at or near the land surface. The fluid levels for the remaining formations below the Cedar Hills Sandstone are unknown, but a differential head of about $1,100 \mathrm{ft}(340 \mathrm{~m})$ across the salt beds seems reasonable. 
Table 2.--Historic records and construction details for wells at four selected sites, central Kansas.

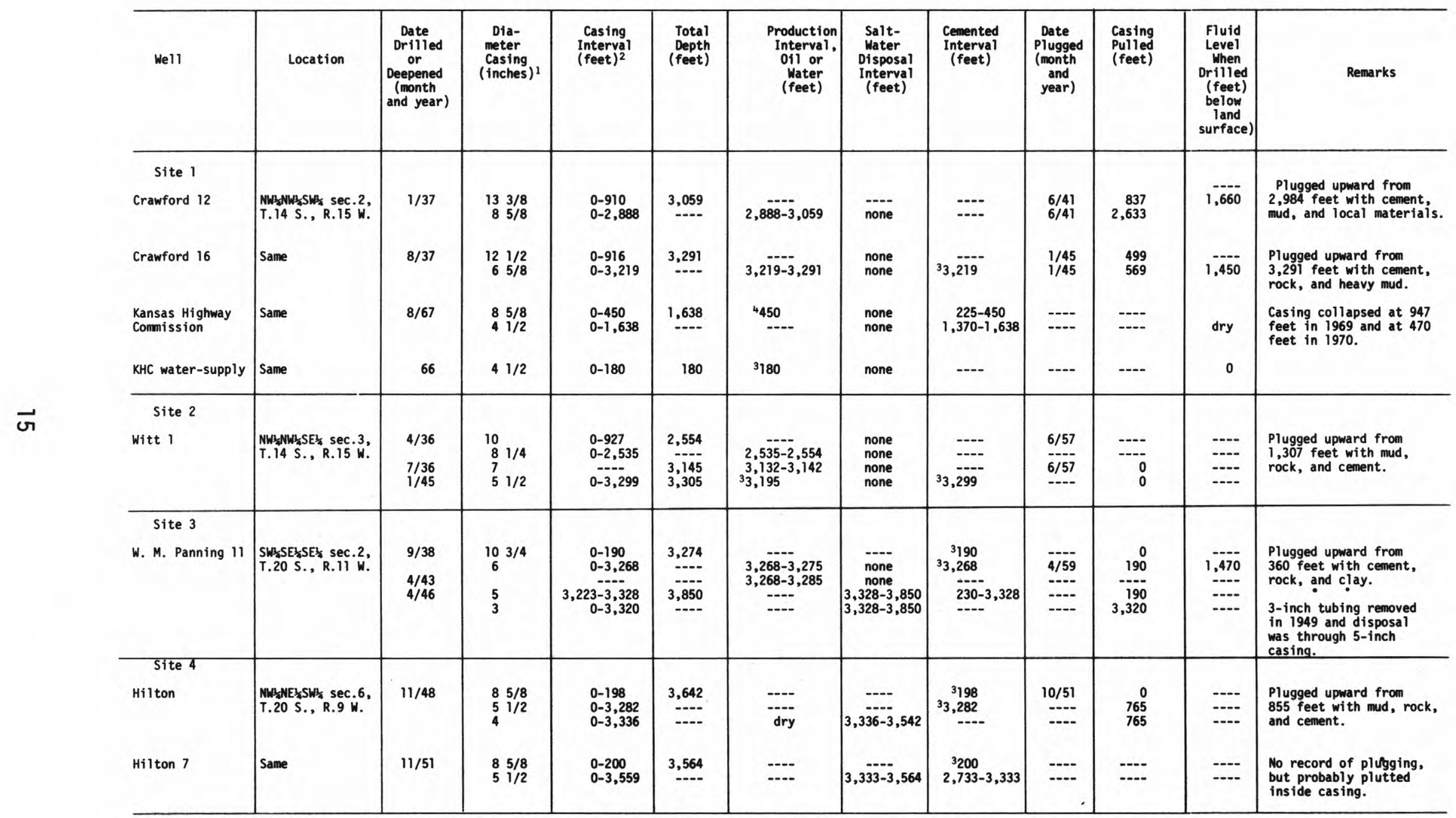

${ }^{1}$ Inches multiplied by 25.4 equivalent to millimetres; ${ }^{2}$ Feet multiplied by 0.3048 equivalent to metres; ${ }^{3}$ Bottom of perforated or cemented interval, top unknown; ${ }^{4}$ Open end casing 


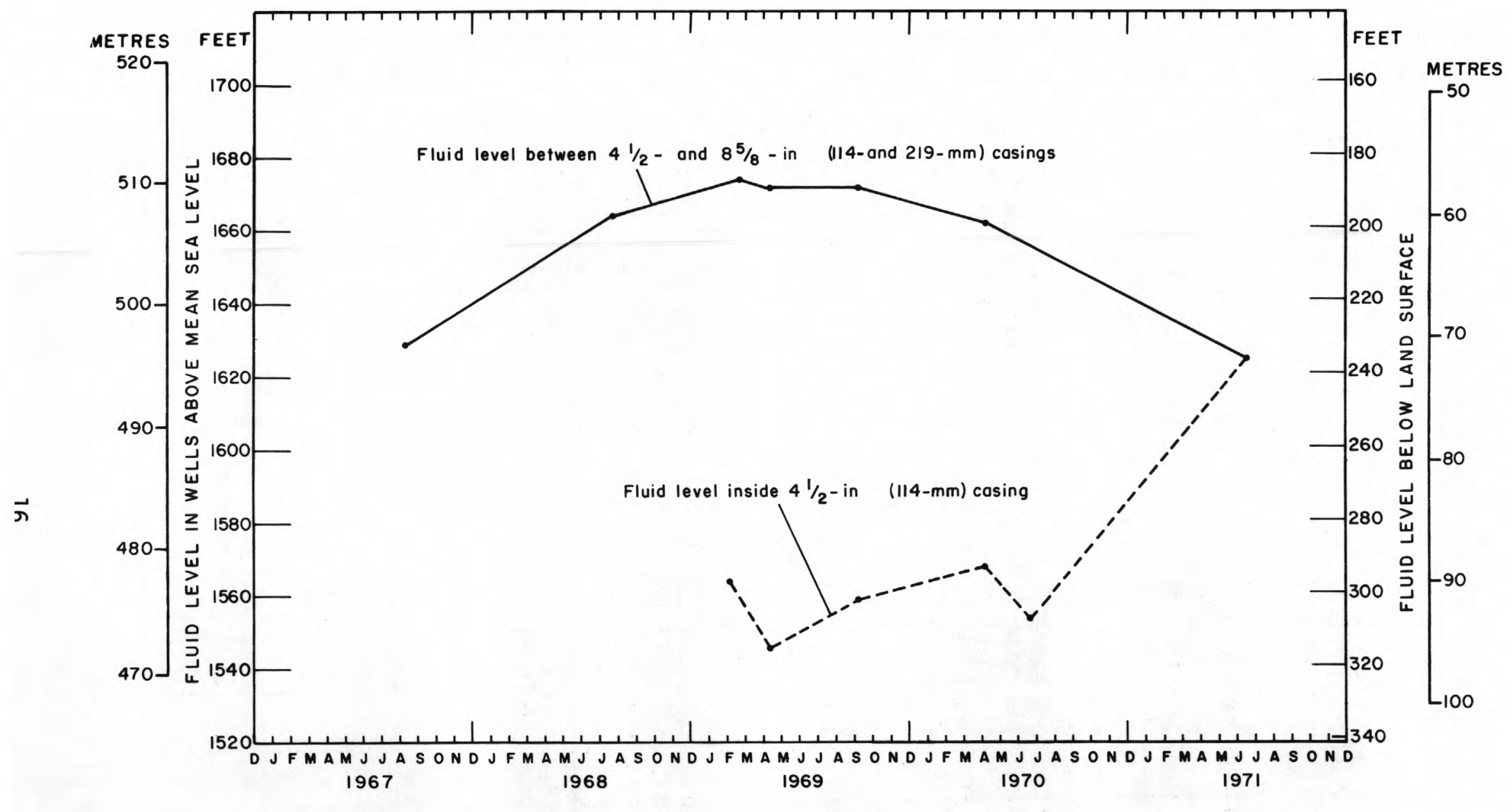

Figure 7.--Fluid levels in Kansas Highway Commission test wells at Site 1. 
The fluid level in the formations above the salt is higher than in the formations below the salt; therefore, any opening or flow path through the salt would facilitate downward movement of water. Corrosion and breakage of the casing left in Crawford 16 at Site 1 after abandoning and plugging probably provides a path for movement and circulation of water through the salt. Even if existing wells had been carefully plugged, deterioration of casings left in place could leave openings that would allow downward movement of water under the pressures involved.

The following assumptions were used to estimate the volume of water needed to dissolve salt at Site 1:

1. The volume of salt removed is equal to the volume of subsidence at the shallow limestone marker bed $\left(4,700,000 \mathrm{ft}^{3}\right.$ or $\left.133,000 \mathrm{~m}^{3}\right)$.

2. The movement of water is downward from the Cheyenne or Cedar Hills Sandstones into the permeable formations below the salt.

3. The concentrations of chloride changed from 3,000 to $150,000 \mathrm{ppm}$ as the fluid circulated through the salt.

4. The volume and mass of dissolved solids, other than sodium, is negligible.

5. Dissolution of salt occurred at an average rate during the 30-year period 1941-70.

6. A11 other factors, such as temperature and pressure, are considered to be constant and any errors caused by such factors are considered to be within the limits of accuracy imposed by the precision of the basic data.

Using the above assumptions, 1 gal $\left(3.785 \times 10^{-3} \mathrm{~m}^{3}\right)$ of salt solution changing from 3,000 to $150,000 \mathrm{ppm}$ of chloride as it circulated through the salt, would dissolve about $0.02 \mathrm{ft}^{3}\left(0.0006 \mathrm{~m}^{3}\right)$ of salt. Therefore, about $235,000,000 \mathrm{gal}\left(890,000 \mathrm{~m}^{3}\right)$ of solution would be needed to dissolve $4,700,000 \mathrm{ft}^{3}\left(133,000 \mathrm{~m}^{3}\right)$ of salt to equal the volume of subsidence at Site 1 . The average rate of flow required to discharge this volume of fluid during 30 years would be about $15 \mathrm{gal} / \mathrm{min}(0.95 \mathrm{l} / \mathrm{s})$. 


\section{SITE 2}

\section{Location}

The sink at Site 2 is centered around an abandoned oil well in the NW $\frac{1}{4} \mathrm{NW}_{\frac{1}{4}} \mathrm{SEE}_{\frac{1}{4}} \mathrm{sec} .3, \mathrm{~T} .14 \mathrm{~S}$., R.15 W., Russell County, about $0.5 \mathrm{mi}(0.8 \mathrm{~km})$ west of Site 1 (fig. 1) and in the same oil field. The location of the well in relation to Interstate Highway 70 is shown in figure 8.

\section{Historical Information}

$0 i 1$ production began in 1935 in the area and more than 50 wells have been drilled within $0.5 \mathrm{mi}(0.8 \mathrm{~km})$ of Site 2. Only Witt 1, an oil well drilled in 1936 and plugged in 1957, has been drilled through the salt beds within the area of subsidence at Site 2 . There were several disposal wells located within $0.5 \mathrm{mi}(0.8 \mathrm{~km})$ of Witt 1 ; the closest disposal well was about $1,320 \mathrm{ft}(400 \mathrm{~m})$ to the south. The closest water-flood injection well was located about $760 \mathrm{ft}(230 \mathrm{~m})$ north of Witt 1 . Sites 1 and 2 are within the same oil-field, therefore, the preceding discussion of disposal wells and water-flooding at Site 1 applies to Site 2.

\section{Geologic and Hydrologic Characteristics}

The lithology and hydrologic properties of the stratigraphic units at Site 2 are similar to those described at Site 1 and, in general, to those given in table 1 .

\section{Subsidence}

Subsidence at Site 2 was first noticed by oil-field workers in 1960 or 1961 when heavy rainstorms caused ponding of water over a lease road. The depression is not apparent on aerial photographs taken in May 1959. The total change in altitude of the land surface at Witt 1 from April 1936 to October 1969 was about $7 \mathrm{ft}(2 \mathrm{~m})$. The area of subsidence in 1969 was about $900 \mathrm{ft}(270 \mathrm{~m})$ in diameter. If this subsidence occurred during 1960-69, the rate of subsidence was about $0.7 \mathrm{ft}(0.2 \mathrm{~m})$ per year. The same rate applies to a surveyed reference point near the well where the land surface subsided $2.2 \mathrm{ft}(0.67 \mathrm{~m})$ from December 1966 to October 1969. 
口-Center of sec. 3, T.14S., R. 15 W.

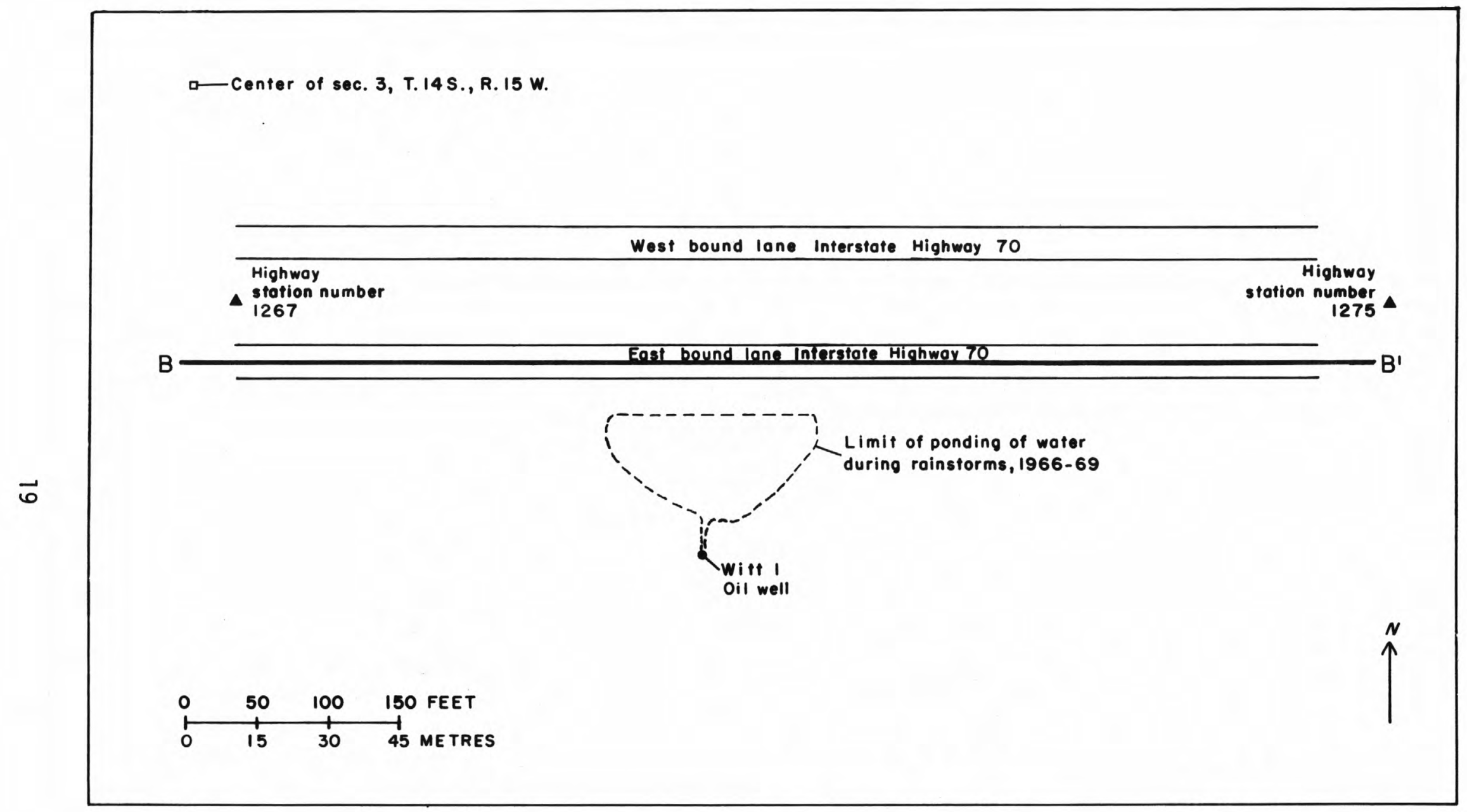

Figure 8.--Sketch of Site 2, showing location of well in relation to the highway. 
Interstate Highway 70 also has been affected by subsidence at Site 2. Figure 9 shows that the east-bound lane of the highway subsided about $4.5 \mathrm{ft}(1.4 \mathrm{~m})$ at station $1270+50$ from 1964 to May 1970 at an average rate of about $0.7 \mathrm{ft}(0.2 \mathrm{~m})$ per year.

The volume of surface subsidence, if represented by a right-circular cone $900 \mathrm{ft}(270 \mathrm{~m})$ in diameter and $7 \mathrm{ft}(2 \mathrm{~m})$ in height (1960-69), would be about $1,500,000 \mathrm{ft}^{3}\left(42,000 \mathrm{~m}^{3}\right)$. Lack of data on formational contacts precludes meaningful estimation of the amount of subsurface subsidence, which probably exceeds $1,500,000 \mathrm{ft}^{3}\left(42,000 \mathrm{~m}^{3}\right)$.

\section{Concentrations of Chloride Ion}

The concentrations of chloride in waters from the geologic formations underlying Site 2 are similar to those listed for Site 1.

\section{Fluid Levels}

The fluid level in Witt 1 , which represents the potentiometric surface of water in the Kansas City and Lansing Groups in 1936, was estimated from nearby wells to be about $1,500 \mathrm{ft}(460 \mathrm{~m})$ below the land surface. Fluid levels in the other formations are not known but are probably at similar depths to those reported for site 1, and the differential head across the salt beds is assumed to be about 1,000 ft $(300 \mathrm{~m})$.

\section{Direction and Rate of Movement of Fluid}

As at Site 1, conditions are such that water would probably move downward from the formations above the salt to those below. Computations similar to those made for Site 1, show that an average rate of $5 \mathrm{gal} / \mathrm{min}$ $(0.3 \mathrm{l} / \mathrm{s})$ of water would be needed to dissolve an amount of salt equivalent to the $1,500,000 \mathrm{ft}^{3}\left(42,000 \mathrm{~m}^{3}\right)$ of surface subsidence at Site 2 during 30 years. 


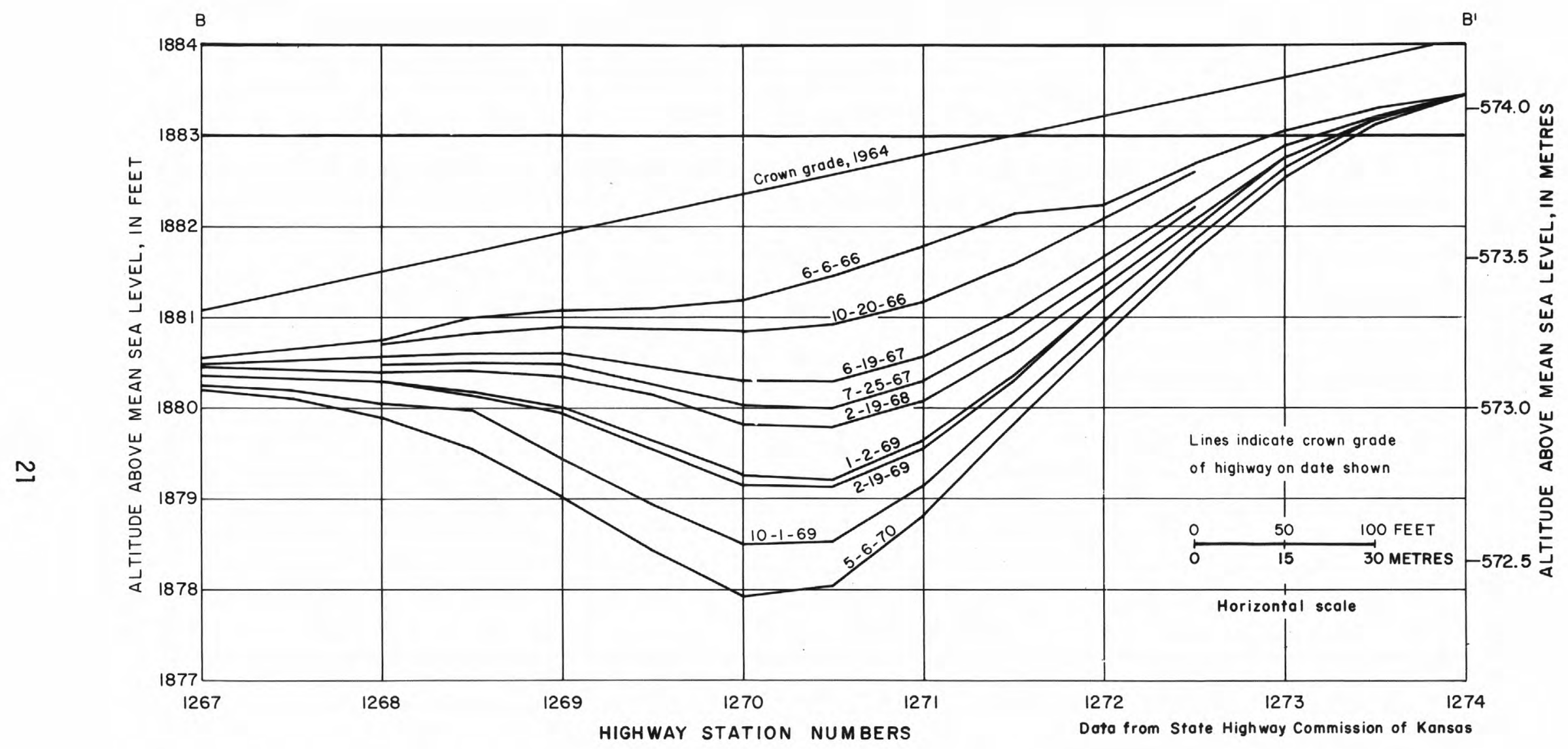

Figure 9.--Profiles of center line of east-bound lane of Interstate Highway 70 at Site 2. 


\section{SITE 3}

\section{Location}

The sink at Site 3 is centered around an oil well that subsequently was used for disposal of brine and then abandoned and plugged. The well is located in the SW $\frac{1}{4} \mathrm{SE}_{\frac{1}{4}}^{\frac{1}{4}} \mathrm{SE}^{\frac{1}{4}} \mathrm{sec} .2, \mathrm{~T} .20 \mathrm{~S}$., R. $11 \mathrm{~W}$. in southeastern Barton County. Photographs of the site are shown in figure 10.
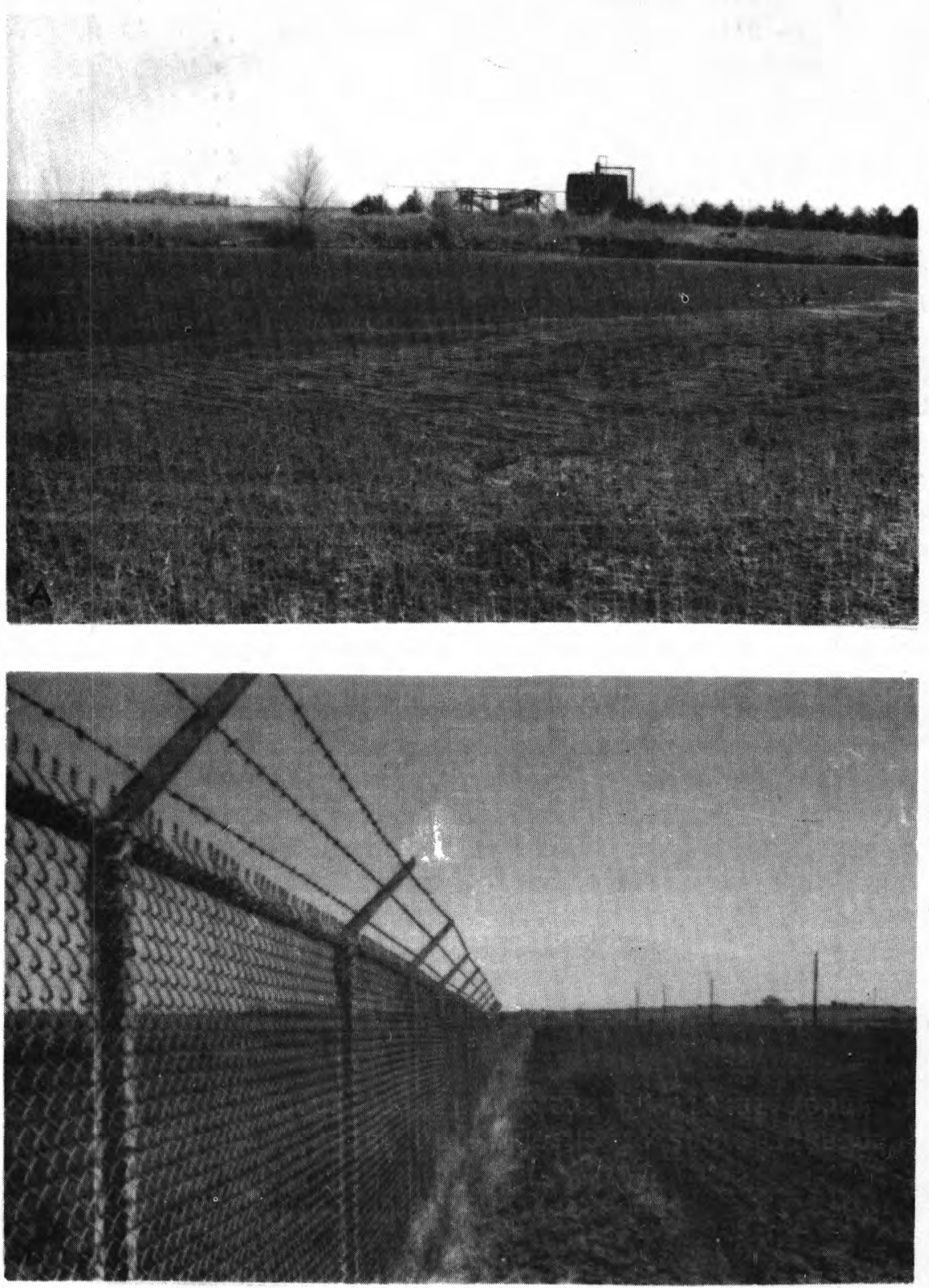

Figure 10.--Photographs of Site 3: A, looking north at eroded pond; B, looking east at surface depression at fence along south side of site. 


\section{Historical Information}

The W. M. Panning 11, which is the only well drilled through the salt within the area of subsidence at Site 3 , was completed as a production well in 1938. The well was deepened in 1946 and used as a disposal well until January 1959. The well was abandoned and plugged on Apri1 14, 1959. The average rate of injection of water during the disposal period 1946-59 was $70 \mathrm{gal} / \mathrm{min}(4 \mathrm{l} / \mathrm{s})$. Although W. M. Panning 11 is surrounded by other $0 i 1$ wells as near as $660 \mathrm{ft}(200 \mathrm{~m})$, the nearest disposal well was about $1,650 \mathrm{ft}(500 \mathrm{~m})$ west of this location. The construction details and related data for the well are given in table 2.

\section{Geologic and Hydrologic Characteristics}

The lithologic and hydrologic properties of stratigraphic units at Site 3 are described in the generalized geologic section shown in table 1. The unconsolidated deposits and the sandstones above the salt beds of the Wellington are potential sources of water for dissolution of the salt. Permeable limestones, dolomite, and conglomerate below the salt, particularly those in the Arbuckle Group, generally will accept water under hydrostatic head.

\section{Subsidence}

Subsidence at Site 3 was first noted by oil-field workers in late 1957 or early 1958. In the winter of 1958-59, the permanent derrick at Panning 11 was tilted, indicating subsidence. At 9:00 a.m. on April 24, 1959, the land owner observed a cavity developing around the well. Clay, silt, sand, and gravel from the collapsed walls of the pit and ground water from the shallow unconsolidated water-table aquifer flowed or washed into the cavity at the well. 0il-field personnel reported that a cone-shaped pit about $300 \mathrm{ft}(90 \mathrm{~m})$ in diameter and $150 \mathrm{ft}(46 \mathrm{~m})$ deep developed within an hour. By the evening of April 24, the groundwater level stabilized at about $55 \mathrm{ft}(17 \mathrm{~m})$ below the land surface. After 1 month, sloughing of the banks reportedly increased the diameter of the pit to about $450 \mathrm{ft}(140 \mathrm{~m})$. At that time, the depth of the pit was reported to be about $38 \mathrm{ft}(12 \mathrm{~m})$. The ground water or pond level was about $6 \mathrm{ft}(2 \mathrm{~m})$ below the general land surface.

An aerial photograph taken in October 1965 shows that the pond at Site 3 was approximately circular and about $330 \mathrm{ft}(100 \mathrm{~m})$ in diameter. Therefore, the author believes that the diameter of about $450 \mathrm{ft}(140 \mathrm{~m})$ reported in April 1959 is excessive for the area of subsidence and that the actual diameter probably was about $320 \mathrm{ft}(98 \mathrm{~m})$. Similarly, the reported $150 \mathrm{ft}(46 \mathrm{~m})$ of collapse within an hour on April 24 appears to be excessive. The depth of $38 \mathrm{ft}(12 \mathrm{~m})$ reported a month later may be too shallow owing to the sloughing of the banks, but the value appears to be of a more reasonable magnitude. 
The volume of subsidence in the subsurface, or the volume of salt dissolved, was probably as much as the volume of the pit 1 month after collapse. If the pit is assumed to be in the shape of a right-circular cone with a diameter of $320 \mathrm{ft}(98 \mathrm{~m})$ and a height of $38 \mathrm{ft}(12 \mathrm{~m})$, the volume would be about $1,000,000 \mathrm{ft}^{3}\left(28,000 \mathrm{~m}^{3}\right)$. If the pit is cylindrical rather than cone-shaped, because of sloughing of the banks, the volume of the pit would be about $3,000,000 \mathrm{ft}^{3}\left(85,000 \mathrm{~m}^{3}\right)$.

Continued subsidence since 1959 is evidenced by the settling and buckling of a protective fence around the pond. By February 1972, subsidence had progressed laterally to the section-line road about $330 \mathrm{ft}(100 \mathrm{~m})$ south of Panning 11 . Projection of the slope of the subsided surface suggests an additional decline of about $7 \mathrm{ft}(2 \mathrm{~m})$, or an additional volume of about $800,000 \mathrm{ft}^{3}\left(23,000 \mathrm{~m}^{3}\right)$. The total volume of salt dissolved as of February 1972, therefore, may have been as much as $3,800,000 \mathrm{ft}^{3}\left(108,000 \mathrm{~m}^{3}\right)$. Although some of the additional subsidence may be due to settiling and compacting of the slumped material, dissolution of salt at Site 3 probably is continuing.

\section{Concentration of Chloride Ion}

The concentration of chloride in water in the formations at Site 3 is estimated from records of nearby wells as follows: Arbuckle Group, 13,000 to 35,000 ppm; Lansing and Kansas City Groups, 30,000 to 33,000 ppm; Dakota Formation, 30 to 1,150 ppm; and unconsolidated deposits, 10 to $100 \mathrm{ppm}$.

\section{Fluid Levels}

The fluid level in well Panning 11 was about $1,470 \mathrm{ft}(450 \mathrm{~m})$ below land surface when the well was completed at a depth of $3,275 \mathrm{ft}(998 \mathrm{~m})$ in 1938. The fluid level in a nearby well, completed at the same depth, was about $2,500 \mathrm{ft}(760 \mathrm{~m})$ below land surface in 1944 . The difference in levels probably reflects a head decline resulting from withdrawals of fluid from the producing zone by nearby wells. The fluid levels in wells in the Permian formations above the salt are unknown, but are assumed to be about $400 \mathrm{ft}(120 \mathrm{~m})$ below the land surface. The fluid level in wells in the Dakota, Kiowa and Cheyenne formations is believed to be about the same level as that in the unconsolidated deposits (the surface of the pond) at Site 3 , which is less than $10 \mathrm{ft}(3 \mathrm{~m})$ below land surface. Therefore, the head differential between the formations above the salt and the formations below is assumed to be at least $1,000 \mathrm{ft}(300 \mathrm{~m})$. 
The fluid levels in the formations above the salt are higher than the fluid levels in the formations below indicating a downward movement of water. Although the date that the dissolution of salt began is unknown, some movement of water through and solution of salt evidently had occurred prior to 1946. The large amount of cement required to seal the liner when the production well was converted to a disposal well indicates that a cavity had already formed (information from construction record on file with Kansas Department of Health and Environment). Because of the uncertainty of the time when solution began, the rate of flow of water needed to dissolve a volume of salt equivalent to the surface subsidence of $3,000,000 \mathrm{ft}^{3}\left(85,000 \mathrm{~m}^{3}\right)$ was computed for two sets of conditions.

If dissolution occurred as a result of circulating relatively fresh ground water through the salt during 1938-59, and the chloride concentration of the fluid changed from 100 to $150,000 \mathrm{ppm}$, an average rate of flow of about $14 \mathrm{gal} / \mathrm{min}(0.9 \mathrm{l} / \mathrm{s})$ would be needed to dissolve a volume of salt equal to the surface subsidence. This amount of water is available from the unconsolidated deposits.

If the dissolution occurred as result of circulating disposal water through the salt during 1946-59, and chloride concentration changed from $35,000 \mathrm{ppm}$ (brine produced with oil) to $150,000 \mathrm{ppm}$ (brine near saturation point), an average rate of flow of about $24 \mathrm{gal} / \mathrm{min}(1.5 \mathrm{l} / \mathrm{s})$ would be needed to dissolve the salt. This rate of flow is less than the average rate of $70 \mathrm{gal} / \mathrm{min}(4.4 \mathrm{l} / \mathrm{s})$ reportedly disposed during the period. 


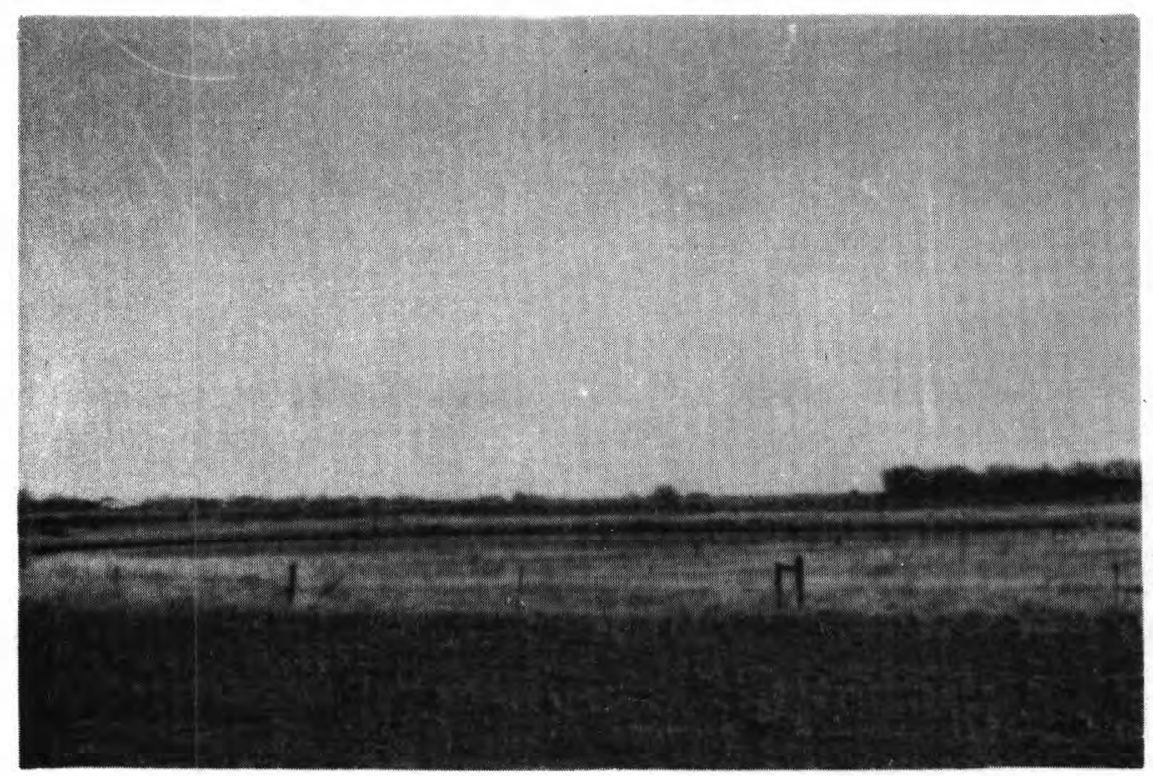

Figure 11.--Site 4, looking northeast at subsidence pond.

\section{SITE 4}

\section{Location}

The sink at Site 4 is centered around two abandoned disposal wells

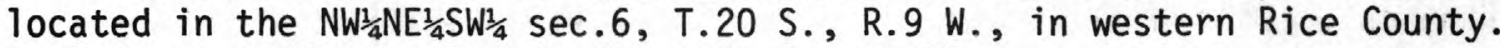
A photograph of the site is shown in figure 11.

\section{Historical Information}

0 il production from wells began near site 4 in 1935, but no producing wells have been drilled at Site 4. A disposal well, designated Hilton 6, was drilled through the salt at the Site in November 1948. Owing to construction problems, the well was subsequently abandoned and plugged. Another disposal well, designated Hilton 7, was drilled in November 1951. The disposal of oil-field brine ceased in 1964 and well Hilton 7 was reportedly plugged by February 1972. The rate of disposal ranged from 10 to $30 \mathrm{gal} / \mathrm{min}(0.6$ to $1.9 \mathrm{l} / \mathrm{s})$ under gravity head at the well.

\section{Geologic and Hydrologic Characteristics}

The lithologic and hydrologic properties of stratigraphic units at Site 4 are described in the generalized geologic section shown in table 1. The unconsolidated deposits near the land surface are the probable source of water for dissolution of salt. The limestone and dolomite below the salt beds, especially in the Arbuckle Group, generally will accept water under hydrostatic head. 
The problems associated with construction and abandonment of well Hilton 6 may have provided the path for downward movement of relatively fresh water and dissolution of salt in 1951. Subsidence at Site 4 was first noted in May 1964 when geologists from the Kansas Department of Health and Environment estimated that $13 \mathrm{ft}(4 \mathrm{~m})$ of decline had occurred during 1948-64. An aerial photograph taken in September 1970 shows a pond at Site 4 with surface dimensions of about 320 by $380 \mathrm{ft}$ ( 98 by $116 \mathrm{~m})$. On the basis of a topographic map, the subsidence during 1948-68 was $18 \mathrm{ft}(5 \mathrm{~m})$ in the center of an area of about 500 by $600 \mathrm{ft}$ $(150$ by $180 \mathrm{~m})$. Considering the surface subisdence to be in the shape of a right-circular cone $550 \mathrm{ft}(170 \mathrm{~m})$ in diameter and $18 \mathrm{ft}(5 \mathrm{~m})$ in height, the volume of subsidence would be about $1,400,000 \mathrm{ft}^{3}\left(40,000 \mathrm{~m}^{3}\right)$. Data are not available to estimate the volume of subsurface subsidence at Site 4 , but it evidently would be equal to or greater than that at the surface.

\section{Concentration of Chloride Ion}

The concentrations of chloride in waters from the geologic formations that underlie Site 4 are similar to those cited for Site 3.

\section{Fluid Levels}

Data about the fluid levels in the formations below the salt in the Wellington at Site 4 are unavailable, but the levels estimated from nearby areas are about $1,000 \mathrm{ft}(300 \mathrm{~m})$ below the land surface. The fluid levels or potentiometric surface for the Permian sandstones above the salt beds are assumed to be at or near the land surface. The fluid level or regional water level in the unconsolidated deposits is assumed to be the surface of the pond at the site. The differential fluid level between the unconsolidated deposits and the formations below the salt beds is assumed to be about $1,000 \mathrm{ft}(300 \mathrm{~m})$.

\section{Direction and Rate of Movement of Fluid}

Because the fluid level in the unconsoldiated deposits probably is about $1,000 \mathrm{ft}(300 \mathrm{~m})$ higher than the fluid level in the formations below the salt, movement of water would be downward. Although the casings left in both wells at Site 4 were reportedly plugged, the casings may have deteriorated or flow channels may have developed outside the casings, which would allow downward movement of relatively low-chloride water through the salt beds. A volume of salt equal to the $1,400,000 \mathrm{ft}^{3}\left(40,000 \mathrm{~m}^{3}\right)$ estimated for the volume of subsidence at the surface could be dissolved by a rate of flow of about $8 \mathrm{gal} / \mathrm{min}(0.5 \mathrm{l} / \mathrm{s})$ of solution changing from 100 to $150,000 \mathrm{ppm}$ of chloride during the 18-year period 1951-68. 


\section{CONCLUSIONS}

Land subsidence at each of the sites investigated for this report probably can be attributed to dissolution and removal of salt from the Wellington Formation and the subsequent collapse of strata overlying the salt zone. Casings or cement plugs apparently have deteriorated, collapsed, or were inadequate to prevent relatively fresh water from moving downward from formations above the salt to formations below the salt. A difference in fluid levels of at least $1,000 \mathrm{ft}(300 \mathrm{~m})$ creates sufficient hydrostatic head to move the dissolved salt from the Wellington into some of the underlying formations. Sufficient quantities of relatively fresh ground water are available above the salt beds at each site to satisfy the estimated rates of dissolution by downward movement of water. Except for the flow of $24 \mathrm{gal} / \mathrm{min}(1.5 \mathrm{l} / \mathrm{s})$ of oilfield brine computed for the disposal period at Site 3, an average flow of $15 \mathrm{gal} / \mathrm{min}$ $(0.9 \mathrm{l} / \mathrm{s})$ could dissolve the volume of salt needed to account for the land subsidence observed at each site.

\section{SELECTED REFERENCES}

Frye, J. C., and Brazil, J. J., 1943, Ground water in the oil-field areas of Ellis and Russell Counties, Kansas: Kansas Geol. Survey Bu11. 50, $104 \mathrm{p}$.

Fent, 0. S., 1950, Geology and ground-water resources of Rice County, Kansas: Kansas Geo1. Survey Bu11. 85, 142 p.

Latta, B. F., 1950, Geology and ground-water resources of Barton and Stafford Counties, Kansas: Kansas Geol. Survey Bul1. 88, 228 p.

Lee, Wallace, 1956, Stratigraphy and structural development of the Saline Basin Area: Kansas Geol. Survey Bul1. 121, 167 p.

Merriam, D. F., 1963, The geologic history of Kansas: Kansas Geol. Survey Bu11. 162, 317 p.

Zeller, D. E., and others, 1968, The stratigraphic succession in Kansas: Kansas Geol. Survey Bu11. 189, 81 p. 
